\title{
Respiratory Function in Pulmonary Thromboembolic Disorders
}

\author{
NORMAN L. JONES,* M.B., M.R.C.P. ; JOHN F. GOODWIN, † M.D., F.R.C.P.
}

Brit. med. F., 1965, 1, 1089-1093

Pulmonary embolism is now known to be a common disorder, but it is often difficult to diagnose, particularly when recurrent embolization gradually leads to the development of obstructive pulmonary hypertension. The abnormalities of pulmonary function produced by emboli have been the subject of several recent reports; many of these studies, however, have been performed in the acute phase following an embolus, and in patients with complicating heart or lung disease or recovering from major operations. As pulmonary function may be disturbed by these conditions, the extent to which the abnormalities found were related to the effects of embolism alone has often been uncertain. In the present work some aspects of pulmonary function have been studied, with particular emphasis on the response to exercise, in a group of patients suffering from thromboembolic pulmonary hypertension or recovering from one or more emboli. In order to establish the extent to which abnormal function reflects the severity of the disease, the results have been related to the findings at cardiac catheterization and to the angiographic appearances.

\section{Materials and Methods}

The clinical details of the 11 patients studied are shown in Table I. They fall into two main groups. In the majority (Cases 4-11) typical pulmonary embolism had occurred on one or more occasions with chest pain, haemoptysis, and the radiographic appearances of pulmonary infarction. In the others (Cases 1-3) the presenting symptoms were mainly due to pulmonary hypertension ; in Case 1 histological evidence of multiple emboli was found at post-mortem examination; in Case 3, previously reported by Goodwin, Harrison, and Wilcken (1963, Case 10), the history suggested repeated pulmonary infarcts. Case 2 was the only patient in whom there was no

\footnotetext{
* Registrar, Department of Medicine, Postgraduate Medical School, Londun. Present address: Cardiovascular Research Institute, San Francisco Medical Center, California, U.S.A
}

† Professor of Clinical Cardiology, Postgraduate Medical School, London. evidence of previous pulmonary infarction; treatment with anticoagulants produced slight improvement in the clinical and electrocardiographic signs, which has been maintained; it seemed most probable that recurrent small emboli were the cause of the pulmonary hypertension.

Patients with complicating conditions known to affect pulmonary function, such as a recent surgical operation and rheumatic or congenital heart disease, were excluded. Two patients suffered from renal disease and one from myelofibrosis, but at the time of study these conditions were not causing symptoms and were not thought to affect the results. The studies were made at varying periods up to one year after the last embolus (see Table III).

The clinical features require little comment (Table I). Peripheral venous thrombosis had occurred in most of the patients. Dyspnoea was common; it was most severe in the patients with chronic pulmonary hypertension, and was absent in only two patients; the grading used in Table $I$ is that of Fletcher (1952).

Clinical signs of pulmonary hypertension (Goodwin et al., 1963) had been noted at some time in six patients, but were present at the time of study in only three (Table III). Electrocardiographic evidence of right ventricular hypertrophy is graded in Table I according to the criteria of Goodwin and Abdin (1959) ; evidence of severe right ventricular hypertrophy was confined to two patients with severe pulmonary hypertension. But $\mathrm{T}$-wave inversion in $\mathrm{V}_{3}$ was an important feature (Goodwin et al., 1963).

Cardiac catheterization was performed in nine patients, haemodynamic data being obtained at rest in the supine position. Gross pulmonary hypertension was present in Cases $1-3$; in three others (Cases 4-6) pulmonary arterial pressures (P.A.P.) were mildly elevated (mean P.A.P. over $20 \mathrm{~mm}$. Hg).

The findings of routine chest radiography were those of cardiac and pulmonary artery enlargement, and other signs associated with present or past emboli. Angiocardiography of

TABLE I.-Clinical, Haemodynamic, and Angiographic Features

\begin{tabular}{|c|c|c|c|c|c|c|c|c|c|c|c|c|c|c|c|c|c|}
\hline \multirow[b]{3}{*}{$\begin{array}{l}\dot{0} \\
\dot{z} \\
0 \\
\tilde{J} \\
\tilde{J}\end{array}$} & \multirow[b]{3}{*}{$\stackrel{\leftrightarrow}{\infty}$} & \multirow[b]{3}{*}{$\stackrel{8}{4}$} & \multicolumn{4}{|c|}{ History } & \multicolumn{3}{|c|}{ Chest $X$-Ray Findings } & \multirow{3}{*}{$\begin{array}{l}\text { Angiographic } \\
\text { Appearances }\end{array}$} & \multicolumn{6}{|c|}{ Cardiovascular Findings } & \multirow{3}{*}{ Comment } \\
\hline & & & \multirow{2}{*}{ 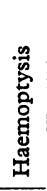 } & \multirow{2}{*}{ 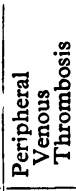 } & \multirow{2}{*}{ 혈. } & \multirow[b]{2}{*}{ 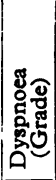 } & \multirow{2}{*}{ 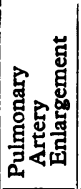 } & \multirow{2}{*}{ 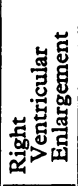 } & \multirow{2}{*}{$\begin{array}{l}\text { Peripheral Lung } \\
\text { Changes }\end{array}$} & & \multirow[b]{2}{*}{ 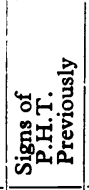 } & \multirow[b]{2}{*}{ 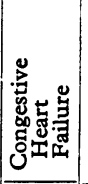 } & \multirow[b]{2}{*}{ نَّ } & \multicolumn{3}{|c|}{$\begin{array}{c}\text { P.A.P. } \mathrm{mm} . \\
\mathrm{Hg}\end{array}$} & \\
\hline & & & & & & & & & & & & & & $\begin{array}{l}.0 \\
\vdots \\
\vdots \\
\vdots \\
\vdots \\
\omega\end{array}$ & 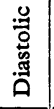 & $\sum^{\mathrm{g}}$ & \\
\hline 1 & $\bar{F}$ & 28 & + & + & 1 & 4 & + & + & $\begin{array}{l}\text { Oligaemia. Small } \\
\text { infarct R.M.Z. }\end{array}$ & Underfilled vessels & + & + & 4 & $\overline{145}$ & 50 & 80 & $\begin{array}{l}\text { Obliterative thromboembolic } \\
\text { hypertension (confirmed }\end{array}$ \\
\hline 2 & $\mathbf{F}$ & 21 & $\mathbf{0}$ & + & - & 4 & + & - & Oligaemia & Not done & + & + & 3 & 95 & .45 & 65 & $\begin{array}{l}\text { Obliterative pulmonary } \\
\text { hypertension improving }\end{array}$ \\
\hline 3 & $\mathbf{F}$ & 35 & 0 & 0 & + & 4 & + & - & Many linear scars & $\begin{array}{l}\text { Widespread vascular } \\
\text { obstruction }\end{array}$ & + & 0 & $0^{*}$ & 60 & 35 & 47 & $\begin{array}{l}\text { with anticoagulatnts } \\
\text { Thromboembolic pulmonary } \\
\text { hypertension }\end{array}$ \\
\hline $\begin{array}{l}4 \\
5\end{array}$ & $\underset{\mathbf{M}}{\mathbf{F}}$ & $\begin{array}{l}56 \\
28\end{array}$ & + & + & $\begin{array}{l}3 \\
1\end{array}$ & $\begin{array}{l}2 \\
2\end{array}$ & + & $\overline{-}$ & $\begin{array}{l}\text { Scar R.M.Z. } \\
\text { Several infarcts }\end{array}$ & $\begin{array}{l}\text { Tortuous vessels } \\
\text { Multiple thrombi }\end{array}$ & $\begin{array}{l}0 \\
+\end{array}$ & $\begin{array}{l}0 \\
0\end{array}$ & R.B.B.B. & $\begin{array}{l}34 \\
35\end{array}$ & 12 & 21 & $\begin{array}{l}\text { Multiple emboli } \\
\text { Multiple emboli. Massive } \\
\text { embolus with spread. }\end{array}$ \\
\hline $\begin{array}{l}6 \\
7\end{array}$ & $\underset{\mathbf{M}}{\mathrm{F}}$ & $\begin{array}{l}42 \\
39\end{array}$ & + & + & $\begin{array}{l}2 \\
1\end{array}$ & 2 & - & $\underline{-}$ & $\begin{array}{l}\text { Normal } \\
\text { Right basal col- } \\
\text { lapse; effusion }\end{array}$ & $\begin{array}{l}\text { Poor peripheral filling } \\
\text { Crowded vessels } \\
\text { R.L.L. }\end{array}$ & $\stackrel{+}{+}$ & $\begin{array}{l}0 \\
0\end{array}$ & $\begin{array}{l}\mathbf{0} \\
\mathbf{0}\end{array}$ & $\begin{array}{l}35 \\
23\end{array}$ & $\begin{array}{r}15 \\
4\end{array}$ & $\begin{array}{l}22 \\
13\end{array}$ & Glomerulonephritis \\
\hline 8 & $\mathbf{M}$ & 51 & + & + & 3 & 3 & + & - & & Not done & + & 0 & 0 & & ot do & & Multiple emboli. \\
\hline $\begin{array}{r}9 \\
10 \\
11\end{array}$ & $\begin{array}{l}\mathbf{M} \\
\mathbf{M} \\
\mathbf{M}\end{array}$ & $\begin{array}{l}65 \\
24 \\
46\end{array}$ & $\begin{array}{l}+ \\
+ \\
+\end{array}$ & $\begin{array}{l}+ \\
+ \\
+\end{array}$ & $\begin{array}{l}1 \\
2 \\
3\end{array}$ & $\begin{array}{l}1 \\
0 \\
0\end{array}$ & $\bar{z}$ & $\begin{array}{l}\bar{z} \\
\overline{-}\end{array}$ & $\begin{array}{l}\text { Normal } \\
\text { Normal } \\
\text { Normal }\end{array}$ & $\begin{array}{l}\text { Not done } \\
\text { Normal } \\
\text { Normal }\end{array}$ & $\begin{array}{l}-\overline{0} \\
0\end{array}$ & $\begin{array}{l}0 \\
0 \\
0\end{array}$ & $\begin{array}{l}0 \\
0 \\
0\end{array}$ & $20^{\mathrm{N}}$ & $\begin{array}{r}\text { ot do } \\
10 \\
7\end{array}$ & $\begin{array}{l}\text { ne } \\
16 \\
13\end{array}$ & Solitary embolus \\
\hline
\end{tabular}


the pulmonary vessels was performed in eight patients. Poor peripheral arterial filling, together with vessel tortuosity and localized blockage, was a common finding. In one patient in whom a massive pulmonary embolus had occurred (Case 5) multiple thrombi were clearly seen as localized "filling defects" in many vessels. In another (Case 7) the only finding was of crowded vessels in an area of partial collapse.

The vital capacity (V.C.) and the volume expired during the first second of a forced expiration (F.E.V.1 ) were measured with a lightweight spirometer (Bernstein, D'Silva, and Mendel, 1952). The total lung capacity (T.L.C.) was measured by a closed-circuit helium dilution technique (Gilson and HughJones, 1955). The diffusing capacity of the lungs for carbon monoxide (DLCO) was measured by the single-breath method of Ogilvie, Forster, Blakemore, and Morton (1957). The last two tests were performed in only the three most seriously affected patients (Cases 1-3).

Pulmonary gas exchange was measured in the sitting position both at rest and during exercise on a bicycle ergometer (Fig. 1). The patients breathed through a low-resistance valve of known dead-space volume; expired gas was collected and ventilation measured, using a Tissot spirometer and kymograph. Expired gas was sampled at the mouth by a mass spectrometer (Associated Electrical Industries-M.S.4), which continuously analysed respired gas for $\mathrm{O}_{2}, \mathrm{CO}_{2}$, and $\mathrm{N}_{2}$. Arterial blood was sampled from a brachial artery, using a small polyethylene catheter inserted percutaneously (Bernéus, Carlsten, Holmgren, and Seldinger, 1954). Expired gas was analysed with the Lloyd-Haldane apparatus (Lloyd, 1958). Blood-gas tensions were measured with the Severinghaus $\mathrm{CO}_{2}$ electrode and the modified Clark polarographic $\mathrm{O}_{2}$ electrode (Severinghaus and Bradley, 1958). The electrocardiogram was recorded, using leads on the chest and forehead in order to minimize muscle artifacts during exercise.

Each patient was studied at least two hours after the last meal. During a preliminary period of rest the arterial catheter was inserted. After this a period was allowed for the patient to become accustomed to breathing through the valve and for adequate flushing of the spirometer. Expired gas was not collected until the mass spectrometer record showed a stable state in end-tidal gas composition. Ventilation was measured and expired gas collected over a three-minute period, arterial blood being sampled at the same time. The patient then exercised at a predetermined work load, and after three to four minutes the spirometer was flushed. A collection of gas and blood was not made until the pulse rate and the end-tidal gas composition were stable. Expired gas and arterial blood were then collected over one and a half minutes. In one patient (Case 2) a very low work load was tolerated for only three

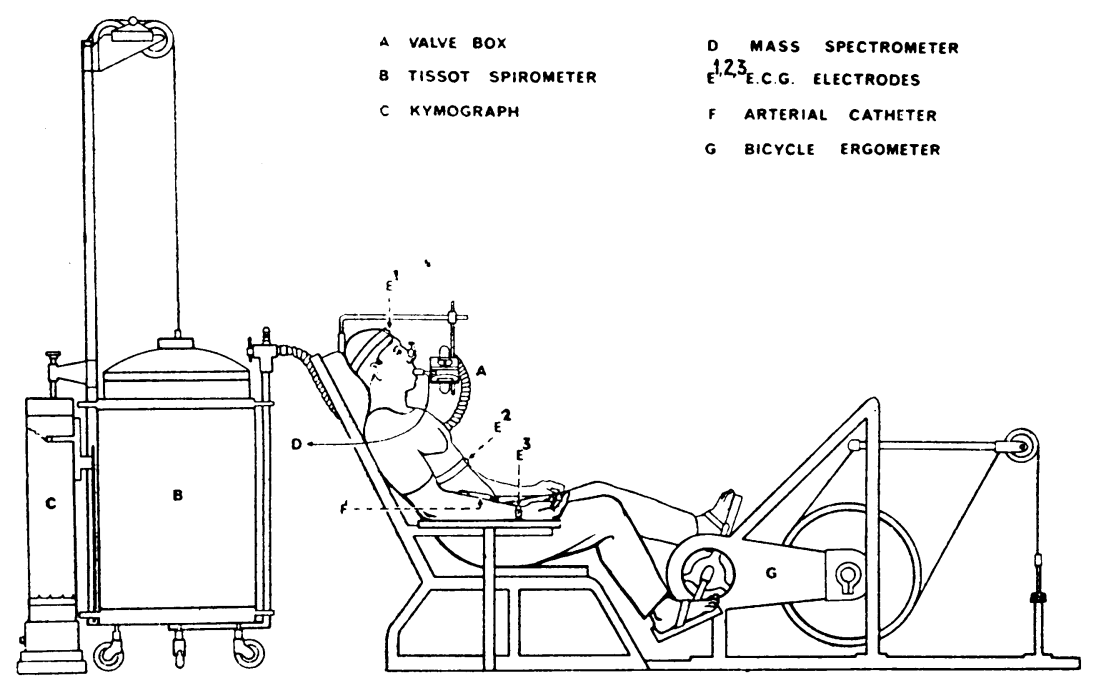

Fig. 1.-Experimental layout used in the exercise studies. minutes: a sample of blood was obtained, but a gas collection could not be got; one patient (Case 3) was not exercised. After exercise the patient breathed $100 \%$ oxygen for 20 minutes; a final blood sample was then taken when the mass spectrometer record confirmed adequate washout of nitrogen.

Minute-ventilation $(\dot{\mathrm{V}} \mathrm{E})$, carbon dioxide output $\left(\dot{\mathrm{V}} \mathrm{CO}_{2}\right)$, and oxygen uptake $\left(\mathrm{VCO}_{2}\right)$ were derived in the usual way from the Tissot record and expired-gas analysis. The dead-space/ tidal-volume ratio (VD/VT) and the physiological dead space (VD) were calculated, using Bohr's formula, after correction for instrumental dead space. The theoretical "ideal " alveolar oxygen tension $\left(\mathrm{PAO}_{2}\right)$ was derived from the alveolar air equation (Fenn, Rahn, and Otis, 1946); the measured arterial oxygen tension $\left(\mathrm{PaO}_{2}\right)$ was substracted from this to obtain the alveolar-arterial oxygen tension difference $\left(\mathrm{A}-\mathrm{aDO}_{2}\right)$.

The measurements of physiological dead space and the alveolar-arterial oxygen tension difference reflect the variations in the balance between ventilation and blood-flow throughout the lungs, and thus yield a measure of the extent to which the lung falls short of being a perfect gas-exchanger. The normal values of these measurements in exercise were obtained from over 50 experiments during 20 studies of normal subjects (Jones, 1964).

\section{Results}

The results of spirometry, lung volumes, and diffusing capacity are shown in Table II. The results of the studies of gas

TABLE II.-Spirometry, Lung Volumes, and Diffusing Capacity (See Text for Abbreviations)

\begin{tabular}{|c|c|c|c|c|}
\hline $\begin{array}{l}\text { Case } \\
\text { No. }\end{array}$ & $\begin{array}{l}\text { F.E.V.1 } \\
\text { 1. B.T.P.S. }\end{array}$ & $\begin{array}{l}\text { V.C. } \\
\text { 1. B.T.P.S. }\end{array}$ & $\begin{array}{l}\text { T.L.C. } \\
\text { 1. B.T.P.S. }\end{array}$ & $\begin{array}{l}\text { DLco } \\
\mathrm{ml} / \mathrm{min} . / \mathrm{mm} . \mathrm{Hg}_{\mathrm{g}}\end{array}$ \\
\hline $\begin{array}{r}1 \\
2 \\
3 \\
4 \\
5 \\
6 \\
7 \\
8 \\
9 \\
10 \\
11\end{array}$ & $\begin{array}{l}2.64 \\
3.19 \\
2.36 \\
2.20 \\
2.68 \\
2.20 \\
3.30 \\
3.00 \\
2.57 \\
5.61 \\
4.20\end{array}$ & $\begin{array}{l}3.19 \\
3.25 \\
3.08 \\
2.75 \\
3.52 \\
3.00 \\
4.07 \\
4 \cdot 10 \\
3.52 \\
6.27 \\
5.25\end{array}$ & $\begin{array}{l}4.50 \\
4 \cdot 68 \\
4 \cdot 24\end{array}$ & $\begin{array}{l}16.0 \\
18.5 \\
14.8\end{array}$ \\
\hline
\end{tabular}

exchange are presented in Table III. Ventilation was often above normal at rest; it was more consistently abnormal during exercise, normal figures being obtained in only two patients, neither of whom showed haemodynamic or angiographic abnormality (Fig. 2). Arterial $\mathrm{PCO}_{2}$ was often below normal limits at rest and during exercise: it was lowest in patients with pulmonary hypertension (Fig. 3). The $\mathrm{VD} / \mathrm{VT}$ ratio was above normal limits at rest in five, and was above normal during exercise in all but two patients (Fig. 4). Physiological dead space (VD) was within the normal range at rest in seven patients, but was normal during exercise in only two (Fig. 5). The $\mathrm{A}-\mathrm{aDO}_{2}$ was normal at rest in four patients, and during exercise in only one patient.

\section{Discussion}

A detailed analysis of the clinical features of the patients studied will not be attempted; recent comprehensive reviews are those of Goodwin et al. (1963) and Wilhelmsen, Selander, Söderholm, Paulin, Vernauskas, and Werkö (1963). Discussion will be limited to some of the abnormalities of lung function produced by pulmonary emboli, their relation to other findings, and the value of the measurements in the assessment of patients with suspected pulmonary thrombo-embolism. 


\section{Abnormalities of Pulmonary Function}

The F.E.V., and V.C. were within the limits of normal (data of Berglund, Birath, Bjure, Grimby, Kjellmer, Sandqvist, and Söderholm, 1963) in all patients, but were in the lower range in several ; similar findings were reported by Wilhelmsen et al. (1963), and by others.

In agreement with previous studies, the T.L.C. was nurmal in the three patients in whom it was measured.

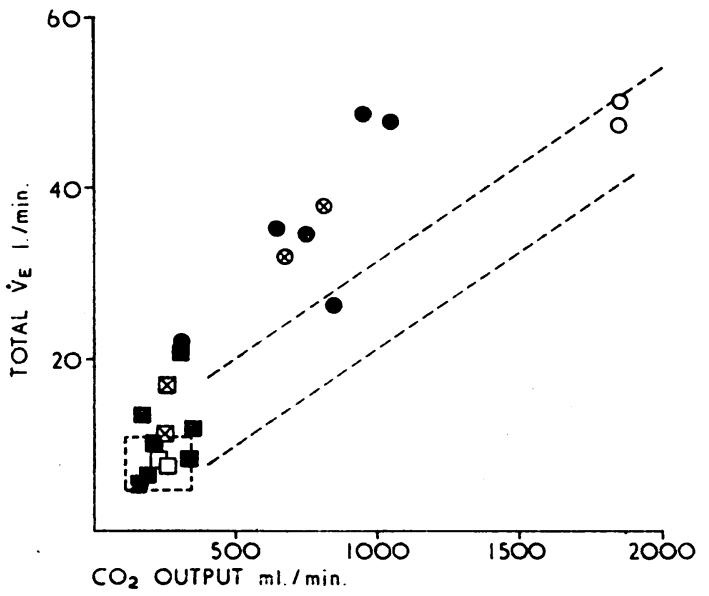

FIG. 2.-Ventilation at rest and during exercise, related to $\mathrm{CO}_{2}$ output. Dotted lines $=$ limits of normal range. Squares $=$ resting values. . Circles $=$ exercise values. Filled symbols = patients with pulmonary hypertension or abnormal angiograms. Open symbols = normal haemodynamics and angiogram. Crossed symbols $=$ catheterization not done.

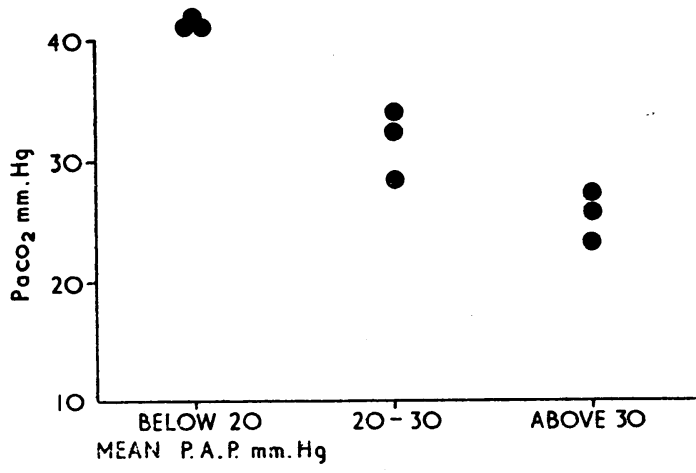

FIG. 3.-Arterial Pco, during exercise related to mean pulmonary artery pressure at rest, illustrating alveolar hyperventilation in patients with pulmonary hypertension.
Dico was below the lower limit of normal $(25 \mathrm{ml}$. CO/min./ $\mathrm{mm} . \mathrm{Hg}$ ) in the three patients in whom it was measured. This reduction is similar to that found by Robin, Forkner, Bromberg, Croteau, and Travis (1960), and Colp and Williams (1962). The reduction in diffusing capacity, as measured by the single-breath carbon-monoxide method, is presumably due to inequalities in the distribution of ventilation and perfusion, and to reduction in the pulmonary capillary blood volume.

The measurements of pulmonary gas exchange showed that the $V_{D} / V_{T}$ ratio and $V_{D}$ were of ten abnormal at rest, and

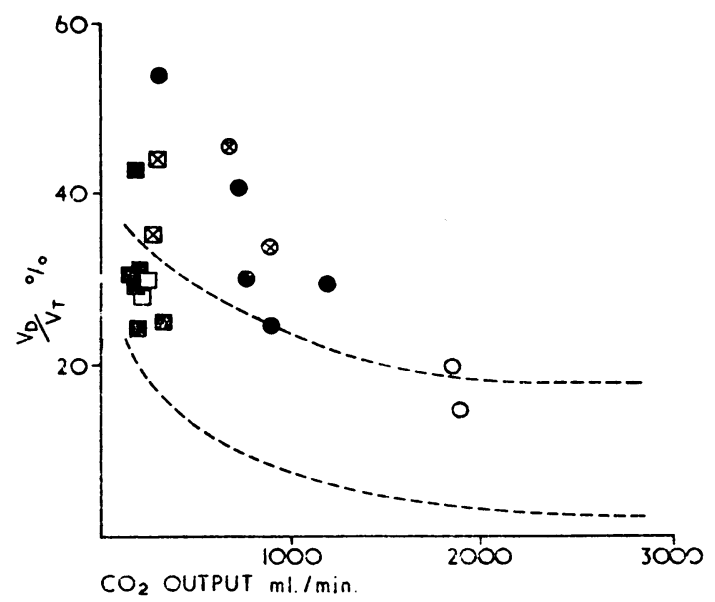

FIG. 4.-VD/VT ratio at rest and during exercise; symbols as in Fig. 2.

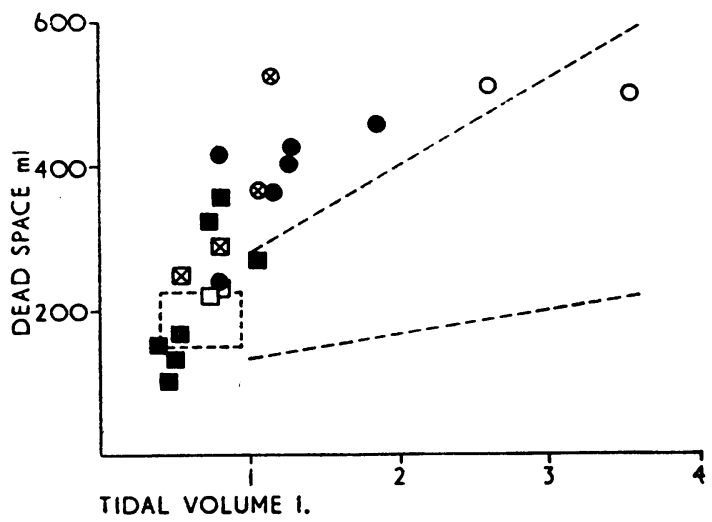

FIG. 5.-Physiological dead space (VD) related to tidal volume $(V T)$ : symbols as in Fig. 2.

TABLE III.-Results of Gas Exchange Studies (see Text for Abbreviations)

\begin{tabular}{|c|c|c|c|c|c|c|c|c|c|c|c|c|c|c|c|}
\hline $\begin{array}{l}\text { Case } \\
\text { No. }\end{array}$ & $\begin{array}{c}\text { Months } \\
\text { Since } \\
\text { Last } \\
\text { Embolus }\end{array}$ & $\begin{array}{c}\text { Clinical } \\
\text { P.H.T. at } \\
\text { Time of } \\
\text { Study } \\
\end{array}$ & Work & $\begin{array}{c}V_{B} \\
\text { 1./min. } \\
\text { B.T.P.S. }\end{array}$ & $\underset{\substack{\mathrm{Vr} \\
\text { ml. } \\
\text { B.T.P.S }}}{\text {. }}$ & $\begin{array}{c}\text { Vcos } \\
\text { ml./min. } \\
\text { S.T.P.D. }\end{array}$ & R.Q. & $\mid \begin{array}{c}\mathrm{PaCO} \\
\mathbf{m m} . \mathrm{Hg}^{\prime}\end{array}$ & $\begin{array}{c}\text { End-tidal } \\
\text { Pcos } \\
\text { mm. } \mathrm{Hg}_{\mathrm{g}}\end{array}$ & $\begin{array}{c}\text { End-tidal } \\
\text { Arterial } \\
\text { Difference } \\
\text { in } \mathrm{PCO}_{2} \\
\end{array}$ & $\begin{array}{l}\mathrm{VD} / \mathrm{VT} \\
\%\end{array}$ & $\begin{array}{l}\text { VD } \\
\text { ml. }\end{array}$ & \begin{tabular}{|c|}
$\mathrm{PaO}_{2}$ \\
$\mathrm{~mm} . \mathrm{Hg}$
\end{tabular} & $\left|\begin{array}{c}\mathrm{A}-\mathrm{aDO} \mathbf{g} \\
\mathrm{mm} . \mathrm{Hg}\end{array}\right|$ & $\begin{array}{c}\mathrm{PaO}_{2} \\
(100 \% \\
\left.\mathrm{O}_{2}\right) \\
\mathrm{mm} . \mathrm{Hg}_{\mathrm{g}} \\
\end{array}$ \\
\hline 1 & $?$ & +\{ & $\begin{array}{l}\text { Rest } \\
75 \text { kg.m. } / \mathrm{min} .\end{array}$ & $\begin{array}{l}13 \cdot 3 \\
22 \cdot 6\end{array}$ & $\begin{array}{l}740 \\
780\end{array}$ & $\begin{array}{l}164 \\
320\end{array}$ & $\begin{array}{l}0.92 \\
1.03\end{array}$ & $\begin{array}{l}21.6 \\
26.8\end{array}$ & $\begin{array}{l}19 \\
23\end{array}$ & $\begin{array}{l}-2.6 \\
-3.8\end{array}$ & $\begin{array}{l}43.6 \\
53.5\end{array}$ & $\begin{array}{l}323 \\
419\end{array}$ & $\begin{array}{r}104 \cdot 2 \\
75 \cdot 4\end{array}$ & $\begin{array}{l}22 \cdot 7 \\
49 \cdot 6\end{array}$ & 595 \\
\hline 2 & $?$ & +\{ & $\begin{array}{l}\text { Rest } \\
50 \mathrm{~kg} / \mathrm{m} / \mathrm{min}\end{array}$ & 5.9 & 457 & 156 & 0.92 & $\begin{array}{l}38.8 \\
27 \cdot 3\end{array}$ & 二 & $=$ & 30.2 & 138 & $\begin{array}{r}97.9 \\
112.7\end{array}$ & 8.8 & 570 \\
\hline $\begin{array}{l}3 \\
4\end{array}$ & $\begin{array}{l}? \\
12\end{array}$ & & $\begin{array}{l}\text { Rest } \\
\text { Rest } \\
250 \text { kg.m.m.min. }\end{array}$ & $\begin{array}{r}21.8 \\
7.1 \\
35.1\end{array}$ & $\begin{array}{l}845 \\
456 \\
775\end{array}$ & $\begin{array}{l}304 \\
171 \\
759\end{array}$ & $\begin{array}{l}0.86 \\
0.87 \\
1.05\end{array}$ & $\begin{array}{l}21.0 \\
32.8 \\
33.8\end{array}$ & $\begin{array}{l}\overline{33} \\
33\end{array}$ & $\begin{array}{r}\overline{0.2} \\
-0.8\end{array}$ & $\begin{array}{l}44 \cdot 5 \\
24 \cdot 0 \\
30 \cdot 0\end{array}$ & $\begin{array}{l}376 \\
108 \\
232\end{array}$ & $\begin{array}{l}75.0 \\
72.4 \\
75.7\end{array}$ & $\begin{array}{l}45 \cdot 0 \\
40 \cdot 6\end{array}$ & 500 \\
\hline 5 & 1 & & $\begin{array}{l}\text { Rest } \\
240 \text { kg.m./min. }\end{array}$ & $\begin{array}{l}11 \cdot 2 \\
49 \cdot 7\end{array}$ & $\begin{array}{r}535 \\
1,242\end{array}$ & $\begin{array}{r}246 \\
1,173\end{array}$ & $\begin{array}{l}0.86 \\
0.94\end{array}$ & $\begin{array}{l}31.5 \\
32.6\end{array}$ & $\begin{array}{l}33 \\
32\end{array}$ & $\begin{array}{r}1.5 \\
-0.6\end{array}$ & $\begin{array}{l}30 \cdot 2 \\
29 \cdot 0\end{array}$ & $\begin{array}{l}161 \\
364\end{array}$ & $\begin{array}{l}95 \cdot 4 \\
87.5\end{array}$ & $\frac{17 \cdot 0}{26 \cdot 3}$ & 479 \\
\hline 6 & 12 & 0\{ & $\begin{array}{l}\text { Rest } \\
110 \text { kg.m./min. }\end{array}$ & $\begin{array}{l}10.9 \\
35.5\end{array}$ & $\begin{array}{r}390 \\
1,267\end{array}$ & $\begin{array}{r}210 \\
710\end{array}$ & $\begin{array}{l}1.09 \\
0.94\end{array}$ & $\begin{array}{l}29.8 \\
28 \cdot 4\end{array}$ & 22 & $\begin{array}{l}-7 \cdot 8 \\
-6 \cdot 4\end{array}$ & $\begin{array}{l}40.3 \\
33.9\end{array}$ & $\begin{array}{l}157 \\
429\end{array}$ & $\begin{array}{r}107.0 \\
98.0\end{array}$ & $\begin{array}{l}12 \cdot 3 \\
20 \cdot 8\end{array}$ & 393 \\
\hline 7 & 1 & & $\begin{array}{l}\text { Rest } \\
200 \text { kg.m./min. }\end{array}$ & $\begin{array}{l}11 \cdot 8 \\
26 \cdot 1\end{array}$ & $\begin{array}{l}1,071 \\
1,857\end{array}$ & $\begin{array}{l}335 \\
880\end{array}$ & $\begin{array}{l}1.02 \\
1.03\end{array}$ & $\begin{array}{l}35 \cdot 3 \\
41 \cdot 5\end{array}$ & $\begin{array}{l}34 \\
41\end{array}$ & $\begin{array}{l}-1.3 \\
-0.5\end{array}$ & $\begin{array}{l}25 \cdot 0 \\
24 \cdot 5\end{array}$ & $\begin{array}{l}267 \\
455\end{array}$ & $\begin{array}{l}71 \cdot 7 \\
78 \cdot 0\end{array}$ & $\begin{array}{l}39 \cdot 3 \\
26 \cdot 4\end{array}$ & 435 \\
\hline 8 & 6 & 0\{ & $\begin{array}{l}\text { Rest } \\
100 \text { kg.m./min. }\end{array}$ & $\begin{array}{l}11.7 \\
30.8\end{array}$ & $\begin{array}{r}554 \\
1,146\end{array}$ & $\begin{array}{l}246 \\
693\end{array}$ & $\begin{array}{l}0.95 \\
1.23\end{array}$ & $\begin{array}{l}39 \cdot 0 \\
39 \cdot 2\end{array}$ & 二 & 二 & $\begin{array}{l}44 \cdot 2 \\
45 \cdot 9\end{array}$ & $\begin{array}{l}245 \\
526\end{array}$ & $\begin{array}{l}79 \cdot 5 \\
73 \cdot 2\end{array}$ & $\begin{array}{l}29.9 \\
43.4\end{array}$ & 531 \\
\hline 9 & 2 & 0\{ & $\begin{array}{l}\text { Rest } \\
300 \mathrm{~kg} . \mathrm{m} . / \mathrm{min} \text {. }\end{array}$ & $\begin{array}{l}17.1 \\
38.0\end{array}$ & $\begin{array}{r}818 \\
1,086\end{array}$ & $\begin{array}{l}280 \\
875\end{array}$ & $\begin{array}{l}0.97 \\
1.05\end{array}$ & $\begin{array}{l}24 \cdot 2 \\
35 \cdot 2\end{array}$ & $\begin{array}{l}20 \\
30\end{array}$ & $\begin{array}{l}-4 \cdot 2 \\
-5 \cdot 2\end{array}$ & $\begin{array}{l}35 \cdot 3 \\
34 \cdot 0\end{array}$ & $\begin{array}{l}288 \\
369\end{array}$ & $\begin{array}{l}94 \cdot 7 \\
84 \cdot 7\end{array}$ & $\begin{array}{l}28 \cdot 0 \\
29 \cdot 1\end{array}$ & 515 \\
\hline 10 & 12 & 0\{ & $\begin{array}{l}\text { Rest } \\
650 \text { kg.m./min. }\end{array}$ & $\begin{array}{r}8 \cdot 9 \\
47 \cdot 3\end{array}$ & $\begin{array}{r}751 \\
3,638\end{array}$ & $\begin{array}{r}229 \\
1,876\end{array}$ & $\begin{array}{l}0.88 \\
0.98\end{array}$ & $\begin{array}{l}37.0 \\
41 \cdot 4\end{array}$ & 三 & 三 & $\begin{array}{l}30 \cdot 0 \\
14.7\end{array}$ & $\begin{array}{l}226 \\
533\end{array}$ & $\begin{array}{l}90 \cdot 3 \\
88 \cdot 2\end{array}$ & $\begin{array}{l}17.0 \\
19.0\end{array}$ & - \\
\hline 11 & 3 & $0\{1$ & $\begin{array}{l}\text { Rest } \\
650 \mathrm{~kg} \cdot \mathrm{m} . / \mathrm{min} \text {. }\end{array}$ & $\begin{array}{r}8.4 \\
50.0\end{array}$ & $\begin{array}{r}759 \\
2,591\end{array}$ & $\begin{array}{r}244 \\
1,845\end{array}$ & $\begin{array}{l}0.88 \\
0.92\end{array}$ & $\begin{array}{l}40 \cdot 0 \\
41 \cdot 6\end{array}$ & $\begin{array}{l}39 \\
45\end{array}$ & $\begin{array}{r}-1 \cdot 0 \\
3 \cdot 6\end{array}$ & $\begin{array}{l}30.9 \\
19.6\end{array}$ & $\begin{array}{l}235 \\
509\end{array}$ & $\begin{array}{l}85 \cdot 7 \\
78 \cdot 3\end{array}$ & $\begin{array}{l}23 \cdot 7 \\
31.0\end{array}$ & 543 \\
\hline
\end{tabular}


almost invariably abnormal during exercise in those patients with haemodynamic abnormality or angiographic evidence of vascular obstruction. The $\mathrm{VD} / \mathrm{VT}$ ratio was measured in five patients by Wilhelmsen et al. (1963), and found to be increased in all ; it was high in the three patients studied by Ehrner, Garlind, and Linderholm (1959). A gross degree of dead-space ventilation occurred during exercise in the case described by Heilman, Tabakin, Hanson, and Naeye (1962). The increase in $\mathrm{VD}$ is due to the presence of ventilated areas in the lung which are devoid of blood supply or which have a high ventilation/perfusion ratio. This "alveolar dead space" is also revealed by a difference between the $\mathrm{PCO}_{2}$ of end-tidal gas and that of arterial blood; an increase in this difference in patients with pulmonary emboli was found by Robin, Julian, Travis, and Crump (1959), who considered that it was quantitatively related to the size of the embolized area of lung. At rest endtidal $\mathrm{PCO}_{2}$ is normally $0-3 \mathrm{~mm}$. $\mathrm{Hg}$ below $\mathrm{PaCO}_{2}$, and values within this range were found in five patients. During exercise it invariably rises to above $\mathrm{PaCO}_{2}$ in normal subjects, to an extent dependent on the $\mathrm{CO}_{2}$ output and the frequency of breathing (Jones, 1964). In contrast, the end-tidal $\mathrm{PCO}_{2}$ was below normal with respect to $\mathrm{PaCO}_{2}$ during exercise in all but one patient (Case 11) of the present study. The finding in some patients of an increased $V D$ and an abnormal end-tidal to arterial $\mathrm{PCO}_{2}$ difference during exercise when these were normal at rest is of interest.

Severinghaus, Swenson, Finley, Lategola, and Williams (1961) found that unilateral pulmonary artery occlusion in anaesthetized dogs produced a prompt fall in the ventilation of the occluded lung due to bronchoconstriction. Similar changes occur in experimental microembolism (Nadel, Colebatch, and Olsen, 1964). The reduction in ventilation in embolized parts of the lung reduces the alveolar dead space, and for this reason measurements of dead space and end-tidal to arterial $\mathrm{PCO}_{2}$ differences may not be quantitatively related to the size of lung affected. The abnormal increase in dead space during exercise in some patients suggests that the reduction in the ventilation of embolized areas may not be maintained during the stress of exercise. Measurements made during exercise may be more closely related to the extent of vascular disease in the lungs than the same measurement made at rest.

The arterial $\mathrm{PCO}_{2}$ was below normal during exercise in patients with pulmonary hypertension (Fig. 3), indicating that alveolar ventilation was excessive for the level of $\mathrm{CO}_{2}$ output in these patients. Alveolar hyperventilation was noted "by Robin et al. (1960) in several of their patients. In the reports of Ehrner et al. (1959) and Wilhelmsen et al. (1963) haemodynamic data were included. The three patients in the former study all had pulmonary hypertension, and all showed a low $\mathrm{PaCO}_{2}$ at rest and during exercise $(20-33 \mathrm{~mm}$. $\mathrm{Hg}) . \mathrm{PaCO}_{2}$ was measured in two of the patients also studied at catheterization by Wilhelmsen et al.: both had pulmonary hypertension$\mathrm{PaCO}_{2}$ was $24-27 \mathrm{~mm}$. $\mathrm{Hg}$ in one and $33-36 \mathrm{~mm}$. $\mathrm{Hg}$ in the other.

In the present study alveolar hyperventilation was most marked in patients with severe hypertension, but was also present in three other patients with mild hypertension. This association raises interesting questions regarding the control of ventilation in these patients. The excessive ventilatory drive is unlikely to be due to classical chemoreceptor mechanisms, for arterial $\mathrm{PCO}_{2}$ is low, arterial $\mathrm{Po}_{2}$ normal or even high (Case 2), and arterial $\mathrm{pH}$ normal or slightly raised (Wilhelmsen et al., 1963). Asmussen and Nielsen (1946) found a close correlation in normal subjects between the hyperventilation of heavy exercise and the degree of anaerobiosis in working muscles. Evidence suggesting excessive anaerobic metabolism during exercise was found in one patient (Case 5), in whom "excess lactate" (Huckabee, 1958) amounted to $2.3 \mathrm{mEq} / 1$. , a high value for the work load (Naimark, Jones, and Lal, 1965). Anaerobic metabolism in working muscle is likely to arise in patients with pulmonary hypertension due to the associated reduction in cardiac output. There is no evidence regarding the part played by other mechanisms, such as reflexes arising in the lung or its vessels, in causing the hyperventilation found in these patients, and more exhaustive studies are needed to investigate this interesting phenomenon.

The $\mathrm{A}-\mathrm{aDO}_{2}$ was normal at rest in four patients; during exercise a normal value was obtained in only one patient (Fig. 6). Increased values were found by Ehrner et al. (1959) and Wilhelmsen et al. (1963); the finding is also implicit in the results of other workers who have reported arterial oxygen

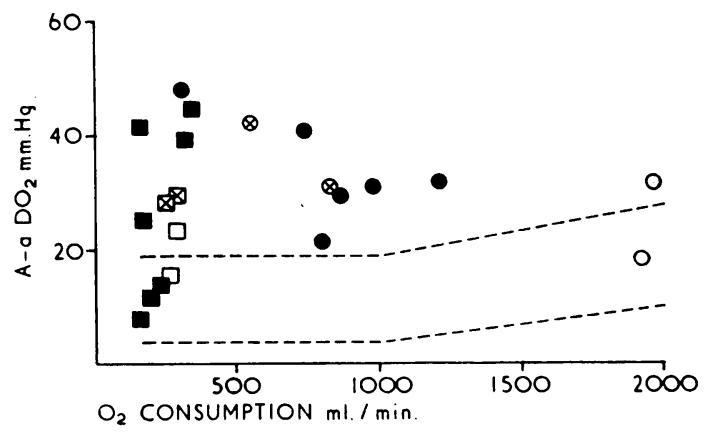

FIG. 6.-Alveolar-arterial oxygen tension difference (A$\mathrm{aDO}_{2}$ ) at rest and during exercise, related to oxygen con-

desaturation in the presence of a normal or low arterial $\mathrm{PCO}_{2}$. Of the three factors influencing the $\mathrm{A}-\mathrm{aDO}_{2}-$ " anatomical " shunting, ventilation-perfusion inequality, and impaired diffusion-the first may be studied during $100 \%$ oxygen breathing. When all the nitrogen has been washed out of the lungs the effect of the other two factors is negligible, and any reduction in arterial $\mathrm{PO}_{2}$ can be assumed to be due to the effect of mixed venous blood which has bypassed ventilated lung. A minor degree of such venous admixture was found in all patients, arterial $\mathrm{Po}_{2}$ being below $600 \mathrm{~mm}$. Hg. In three patients the arterial $\mathrm{Po}_{2}$ was below $500 \mathrm{~mm}$. $\mathrm{Hg}$, indicating that more than about $8 \%$ of the total cardiac output was being shunted.

Although shunting could occur through anastomoses between the pulmonary and the bronchial circulations, this seems unlikely in view of the fact that it was negligible in degree in the two patients with the most severe pulmonary hypertension. The most marked degree of anatomical shunting was found in Case 7 , in whom it was presumably related to the angiographic finding of normal blood-flow in an atelectatic area of lung. Severinghaus et al. (1961), in their experiments on anaesthetized dogs, found anatomical shunting on restoring the blood-flow in a previously occluded pulmonary artery; hyperinflation of the lung produced a reduction in shunting. It seems likely that anatomical shunting in patients is due mainly to non-ventilated areas of lung which have retained their blood-flow. In most patients it is of minor degree and contributes less than $10 \mathrm{~mm}$. $\mathrm{Hg}$ to the $\mathrm{A}-\mathrm{aDO}_{2}$ during air-breathing at rest; the main factor causing the $\mathrm{A}-\mathrm{aDO}_{2}$ is an inequality in the ventilationperfusion ratio in the lung. The studies of experimental pulmonary embolism reported by Nadel et al. (1964) have demonstrated constriction of alveolar ducts following embolization; this probably contributes to the $\mathrm{A}-\mathrm{aDO}_{2}$ during both airbreathing and $100 \% \mathrm{O}_{2}$-breathing.

The reduction in pulmonary capillary blood volume which occurs in patients with widespread thromboembolism will lead to a reduction in the diffusing capacity for oxygen. This may contribute to the $\mathrm{A}-\mathrm{aDO}_{2}$, but it is difficult to assess this factor with present methods; its contribution is likely to be small at the high levels of alveolar oxygen tension usually found in these patients.

Significant arterial desaturation $-\mathrm{PaO}_{2}$ less than $70 \mathrm{~mm} . \mathrm{Hg}$, saturation below $92 \%$ - was found in only one patient. It does not appear to be related to the presence of pulmonary hypertension in the present series, although it has been reported in patients with thromboembolic pulmonary hypertension by Goodwin et al. (1963) and Wilhelmsen et al. (1963). 


\section{Relation of Abnormal Pulmonary Function to Other Findings}

The results of the gas-exchange studies suggest that they may be a useful guide to the severity of the vascular disease. The association between alveolar hyperventilation and pulmonary hypertension requires further study in a larger series of patients, especially to clarify the mechanisms involved; the relation does, however, appear to be confirmed by the findings of previous workers already mentioned.

The measurement of physiological dead space and the VD/ VT ratio, especially during exercise, seem to be a guide to the extent of the vascular obstruction: both were abnormal in the patients with pulmonary hypertension or abnormal angiograms. The $\mathrm{VD} / \mathrm{VT}$ ratio was within the upper limit of normal (Fig. 4) in Cases 7 and 10, and slightly raised in Case 11. In these three patients there was no angiographic evidence of vascular occlusion; in Cases 10 and 11 the angiogram was normal, and in Case 7 localized arterial crowding was seen with normal flow.

The $\mathrm{A}-\mathrm{aDO}_{2}$ is another sensitive indicator of pulmonary disease, only Case 10 showing a normal value during exercise. As it is related to areas in the lung with a low ventilationperfusion ratio, it tends to be raised shortly after a pulmonary embolus when alveolar duct constriction (Nadel et al., 1964) may be expected to be maximal. This was seen in one patient (Case 7), who was studied a few days after acute infarction as well as during recovery a month later. Shortly after infarction the $\mathrm{A}-\mathrm{aDO}_{2}$ was $59.6 \mathrm{~mm}$. $\mathrm{Hg}$; a month later it was 39.3 at rest, and 26.4 during exercise.

Simple spirometry and the measurement of lung volumes do not help in the assessment of severity in these patients, but help to exclude other forms of lung disease. The diffusing capacity for CO was moderately reduced in the three most severely affected patients. This measurement may yield a measure of the degree of vascular disease. We did not analyse Dico into its two components of pulmonary capillary blood volume (Vc) and resistance of the alveolar-capillary membrane (DM), and it is possible that the measurement of VC would be of value.

\section{Value of the Exercise Technique}

The results underline the importance of making the measurements of pulmonary gas exchange during exercise as well as at rest ; minor abnormalities are more likely to be detected under the stress of exercise. There are, in addition, several other advantages to the exercise study. An objective measure of exercise tolerance is obtained, and from the relation between the pulse frequency and the work load the cardiac response to exercise may be assessed. The "functional" overventilation which commonly occurs in anxious patients is less likely to occur during exercise than at rest. The "unsteady state" produced by such overventilation may lead to errors in gasexchange measurements; these errors are minimized if the measurements are made in exercise, when equilibration of the body gas stores will be more rapid.

The gas-exchange studies are valuable in assessing progress as they may be more sensitive indicators than cardiac catheterization and angiography, and can be conveniently performed on out-patients. Furthermore, the electrocardiogram, although of ten a most valuable guide to continuing pulmonary thromboembolism, may occasionally show only $\mathrm{T}$-wave changes, as in the patient (Case 3) who had a normal graph apart from $\mathrm{T}$ wave inversion in lead V3.

Because of the increased dead space ventilation and the frequent presence of alveolar hyperventilation, total ventilation was excessive for the work load in all but Cases 7, 10, and 11 (Fig. 2), in whom there was little significant vascular disease. The measurement of ventilation and $\mathrm{CO}_{2}$ output during exercise thus seems to be a valuable screening procedure which is simple to perform, and does not require bloodsampling; a normal relation between the two is likely to be obtained only in patients without alveolar hyperventilation and with a normal dead space. The results suggest that such patients are unlikely to have significant pulmonary vascular disease.

\section{Summary}

Pulmonary function has been investigated in three patients with severe thromboembolic pulmonary hypertension and eight others who had had pulmonary emboli, with particular emphasis on the response of pulmonary gas exchange to exercise. The findings were related to abnormalities of haemodynamics and of the pulmonary circulation as shown by cardiac catheterization and angiography.

Ventilatory capacity was within normal limits in all patients. Lung volumes were normal, and the diffusing capacity for carbon monoxide was moderately reduced in the three patients with pulmonary hypertension.

Total ventilation during exercise was abnormally high in all patients with haemodynamic or radiological abnormality, and its measurement is suggested as a simple screening procedure. The increased total ventilation was due both to alveolar hyperventilation and to ventilation of dead space. The former was more prominent in patients with pulmonary hypertension. Increased dead-space ventilation occurred during exercise in patients showing angiographic abnormality. The higher incidence of dead-space ventilation during exercise than at rest suggested that embolized areas in the lung which are not ventilated at rest become ventilated during exercise.

The alveolar-arterial oxygen tension difference was abnormal during exercise in all patients with haemodynamic or angiographic abnormality. It was due partly to " anatomical " shunting of blood, and partly to inequality in the ventilationperfusion relationships in the lung.

The results are discussed in relation to the control of ventilation and the factors which cause abnormal function and pulmonary hypertension.

It is concluded that the measurement of pulmonary gas exchange, especially during exercise, is of value in the physiological assessment of patients with pulmonary vascular disease.

We are grateful to Dr. E. J. Moran Campbell for his helpful advice, and to Mrs. E. Wines and Miss H. Pope for technical assistance. The radiological advice of Professor R. E. Steiner is warmly acknowledged.

\section{REFERENCES}

Asmussen, E., and Nielsen, M. (1946). Acta physiol. scand., 12, 171. Berglund, E., Birath, G., Bjure, J., Grimby, G., Kiellmer, I., Sandqvist, L., and Söderholm, B. (1963). Acta med. scand., 173, 185.

Bernéus, B., Carlsten, A., Holmgren, A., and Seldinger, S. I. (1954) Scand. \%. clin. Lab. Invest., 6, 217.

Bernstein, L., D'Silva, J. L., and Mendel, D. (1952). Thorax, 7, 255. Colp, C. R., and Williams, M. H. (1962). Amer. Rev. rosp. Dis., 85, 799.

Ehrner, L., Garlind, T., and Linderholm, H. (1959). Acta med. scand., $164,279$.

Fenn, W. O., Rahn, H., and Otis, A. B. (1946). Amer. F. Physiol., 146, 637.

Fletcher, C. M. (1952). Proc. roy. Soc. Med., 45, 577.

Gilson, J. C., and Hugh-Jones, P. (1955). Spec. Rep. Ser. med. Res. Coun. (Lond.), No. 290.

Goodwin, J. F., and Abdin, Z. H. (1959). Brit. Heart f., 21, 523.

Harrison, C. V., and Wilcken, D. E. L. (1963). Brit. med. F., 1,701 .

Heilman, R. S., Tabakin, B. S., Hanson, J. S., and Naeye, R. L. (1962). Amer. F. Med., 32, 298.

Huckabee, W. E. (1958). \%. clin. Invest., 37, 244.

Jones, N. L. (1964). "Pulmonary Gas Exchange During Exercise." M.D. Thesis, London University.

Lloyd, B. B. (1958). ₹. Physiol. (Lond.), 143, 5P.

Nadel, J. A., Colebatch, H. J. H., and Olsen, C. R. (1964). F. appl. Physiol., 19, 387.

Naimark, A., Jones, N. L., and Lal, S. (1965). Clin. Sci., 28, 1.

Ogilvie, C. M., Forster, R. E., Blakemore, W. S., and Morton, J. W. (1957). ₹.' clin. Invest., 36, 1.

Rabin, E. D., Forkner, C. E., Bromberg, P. A., Croteau, J. R., and Travis, D. M. (1960). New Engl. F. Med., 262, 283.

Julian, D. G., Travis, D. M., and Crump, C. H. (1959). Ibid., 260, 586 .

Severinghaus, J. W., and Bradley, A. F. (1958). f. appl. Physiol., 13, 515.

Swenson, E. W., Finley, T. N., Lategola, M. T., and Williams, J. (1961). Ibid., 16, 53.

Wilhelmsen, L., Šelander, S., Söderholm, B., Paulin, S., Vernauskas, E., and Werkö, L. (1963). Medicine (Baltimore), 42, 335. 